\title{
Mitigation of salt stress in wheat seedlings by halotolerant bacteria isolated from saline habitats
}

\author{
Dhanushkodi Ramadoss, Vithal K Lakkineni, Pranita Bose, Sajad Ali and Kannepalli Annapurna*
}

\begin{abstract}
Eighty four halotolerant bacterial strains were isolated from the saline habitats and screened for growth at different $\mathrm{NaCl}$ concentrations. All grew well at $5 \% \mathrm{NaCl}$, but only $25 \%$ isolates showed growth at $20 \% \mathrm{NaCl}$ concentration. Five strains SL3, SL32, SL35, J8W and PU62 growing well in 20\% NaCl concentrations were further characterized for multiple plant growth promoting traits such as indole -3- acetic acid (IAA) production, HCN and siderophore production, ACC deaminase activity and P-solubilization. None were positive for HCN production and PCR amplification of acdS, the structural gene for ACC deaminase enzyme was found negative. 16S rRNA gene sequencing analysis of the five strains showed them to belong to two genera Bacillus and Hallobacillus. In vitro experiments showed that salt concentrations had significant inhibitory effects on development of seedlings but not on the growth of the bacterial strains. Inoculation of the 5 halotolerant bacterial strains to ameliorate salt stress $(80 \mathrm{mM}, 160 \mathrm{mM}$ and $320 \mathrm{mM}$ ) in wheat seedlings produced an increase in root length of $71.7 \%$ in comparison with uninoculated positive controls. In particular, Hallobacillus sp. SL3 and Bacillus halodenitrificans PU62 showed more than $90 \%$ increase in root elongation and $17.4 \%$ increase in dry weight when compared to uninoculated wheat seedlings at $320 \mathrm{mM} \mathrm{NaCl}$ stress indicating a significant reduction of the deleterious effects of $\mathrm{NaCl}$. These results indicate that halotolerant bacteria isolated from saline environments have potential to enhance plant growth under saline stress through direct or indirect mechanisms and would be most appropriate as bioinoculants under such conditions.
\end{abstract}

Keywords: Halotolerant bacteria, Salt stress, Wheat, Plant growth promoting bacteria

\section{Introduction}

Salinity is one major limiting factor to plant growth and crop productivity [1]. Cultivated soils worldwide are becoming more saline from marginal irrigation water, excessive fertilization, and desertification processes. Currently, more than 800 million hectares of land throughout the world are affected by levels of salt that could substantially reduce crop productivity [2]. Strategies for alleviation of salt stress involve developing salt-resistant cultivars, leaching excess soluble salts from upper to lower soil depths, flushing soils that contain soil crusts at the surface, reducing salt by harvesting salt-accumulating aerial plant parts in areas with negligible irrigation water or rainfall for leaching, and amelioration of saline soils under cropping and leaching [3]. An alternative is to alleviate salt stress by inoculating crop seeds and seedlings with plant growth

\footnotetext{
* Correspondence: annapurna96@gmail.com

Division of Microbiology, Indian Agricultural Research Institute, New Delhi 110012, India
}

promoting bacteria (PGPB). Looking into the perspectives of crop production losses due to the severity of abiotic stresses, especially salinity, tolerance to stress provided by microbial inoculants becomes more important. Beneficial effect of PGPB under salinity has been related to hydraulic conductance, osmolyte accumulation, sequestering toxic $\mathrm{Na}^{+}$ions, maintaining higher stomatal conductance and photosynthetic activities [4].

Azopsirillum halopraeferens, tolerates $3 \% \mathrm{NaCl}$ [5], colonizes mangrove roots in seawater [6], and enhances the growth of halophytes irrigated with seawater [7]. Most other Azospirillum species can tolerate only 2\% $\mathrm{NaCl}$. Similarly, some Bacilli strains able to tolerate $8 \%$ $\mathrm{NaCl}$ and showing PGP activities have been reported by Upadhyay et al. [8]. PGPB with ACC deaminase activity have been successfully used to reduce the negative effects of salinity by lowering stress ethylene production in the vicinity of growing root [9-12]. Mayak et al. [9] reported that ACC deaminase producing salt tolerant

\section{Springer}

(C) 2013 Ramadoss et al.; licensee BioMed Central Ltd This is an Open Access article distributed under the terms of the Creative Commons Attribution License (http://creativecommons.org/licenses/by/2.0), which permits unrestricted use, distribution, and reproduction in any medium, provided the original work is properly cited. 
bacteria can survive well in a saline environment and that their beneficial properties help plants to overcome stress effects. Halotolerant bacteria are a group of bacteria able to grow well in media containing a wide range of $\mathrm{NaCl}(1-33 \%)$ or in the absence of $\mathrm{NaCl}$ [13]. Hence, it was hypothesized that isolating bacteria with PGP activities from naturally saline habitats would give bonafide candidates which could help ameliorate saline stress effect on wheat plants. Microorganisms surviving at extreme environmental conditions have been found suitable for use in different agricultural practices [14].

Wheat (Triticum aestivum L.) is a major staple food crop for more than one third of the world population and is the main staple food of Asia [15]. Seed germination and seedling growth of wheat, like other crops, were negatively affected by drought and salinity stresses [16]. Salinity stress adversely affects total dry matter and plant growth, as most of the energy available is used in to make osmotic adjustments by the plant [17]. The screening of salt tolerant lines/cultivars has been attempted by many researchers on various species at seedling growth stage [18]. Both water availability and salt stress can impair coleoptiles growth, thus affecting seedling establishment in the field $[19,20]$. The relation of various seedling growth parameters like early emergence and fast seedling growth to seed yield and yield components under saline conditions are important for the development of salt tolerant cultivar for production under saline soil condition. The use of rhizobacteria is one of the most acceptable approaches to reduce the effect of salt-stress on plants as they are endowed with mechanisms which either modulate or ameliorate the salt stress $[4,21]$. Wheat is grown both as winter and spring crop in India and is cultivated under rainfed conditions where precipitation is less than $850 \mathrm{~mm}$ annually. Salinity is one of the major constraints which hamper wheat production in the country. Hence, the present study was conducted in an attempt to isolate and characterize halotolerant bacteria from saline habitats e.g. Sambhar salt lake, Jaiselmer saline soils and Pushkar lake and evaluate check their ability to ameliorate saline stress and improve seedling germination of wheat under salt affected conditions.

\section{Results}

\section{Isolation and screening of salt tolerant bacteria}

Eighty four bacterial strains were selected based on distinct morphology on nutrient agar (NA) $(1 \% \mathrm{NaCl})$ plates. Colonies were selected based on colour, shape, size and abundance. These were screened for salt tolerance and growth in nutrient broth amended with various concentrations of $\mathrm{NaCl}$. Growth was measured after every 24 hours till the seventh day. All grew well in 5\% $\mathrm{NaCl}$. 24 isolates from Pushkar lake, 29 isolates from
Sambhar lake and 6 isolates from Jaiselmer soil grew well in $10 \% \mathrm{NaCl}, 4$ isolates from Pushkar lake, 19 isolates from Sambhar lake and 4 isolates from Jaiselmer soil grew well in $15 \% \mathrm{NaCl}$ and 3 isolates from Pushkar and 16 isolates from Sambhar lake grew in $20 \% \mathrm{NaCl}$. There was a gradual decrease in number of isolates growing at higher salt concentrations. From the total isolates $92.8 \%, 70 \%, 32 \%$ and $25 \%$ of bacterial isolates grew well in 5, 10, 15 and $20 \% \mathrm{NaCl}$ respectively. Isolates from soil were tolerant to maximum of $15 \%$ $\mathrm{NaCl}$ where as water isolates showed higher tolerance limits (Figure 1).

\section{Identification and phylogenetic analysis}

The 16S rDNA of selected five halotolerant bacteria were amplified. Gel electrophoresis of undigested amplified products revealed that all isolates produced a single band of about $1500 \mathrm{bp}$. On the basis of nucleotide sequences of the 16S rDNA fragments the selected strains were identified as Hallobacillus sp (SL3), Bacillus pumilus (SL32), Bacillus sp (SL35), Bacillus sp (J8W) and. Bacillus halodenitrificans (PU62) (Table 1). Phylogenetic analyses of the five strains based on NJ method with 1000 boot strap sampling resulted into three cultures (Figure 2). Hallobacillus sp. SL3 formed cluster I, cluster II was formed with two strains Bacillus $s p$ (SL35) and Bacillus halodenitrificans (PU62) and cluster III had Bacillus pumilus (SL32) and Bacillus sp (J8W).

\section{Characterization for PGP activities of selected strains}

SL3 and J8W were positive for IAA production developing pink color on NA + Trp plate, PU62 solubilized insoluble form of phosphorus, e.g. tri calcium phosphate on Pikovaskya plate. Three isolates, SL3, SL 32 and PU 62 produced siderophores. An orange halo around the colony growth was observed. None of the five isolates produced HCN (Table 1). PCR amplification for acdS was found negative (Figure 3) and no ACC deaminase activity was observed under in vitro conditions in all the five isolates.

\section{Halotolerant bacterial inoculation effect on wheat seedlings under salt stress}

All the five halotolerant strains were able to significantly promote the growth of wheat seedlings in the presence of salt. Salt stress $(160 \mathrm{mM})$ reduced root length by $58.9 \%$ and dry weight biomass by $51 \%$ in 7 day old seedling when compared with the negative control. Inoculation per se had beneficial effects on the root length and root biomass. Under no salt conditions, inoculation improved root length by $11 \%$ and root biomass by $31 \%$. All the tested halotolerant strains were able to improve root length by between $21.8 \%$ and $84.7 \%$ at $80 \mathrm{mM}, 44 \%$ and $117 \%$ at $160 \mathrm{mM}$ and $24 \%$ and $96 \%$ at $320 \mathrm{mM}$ of 


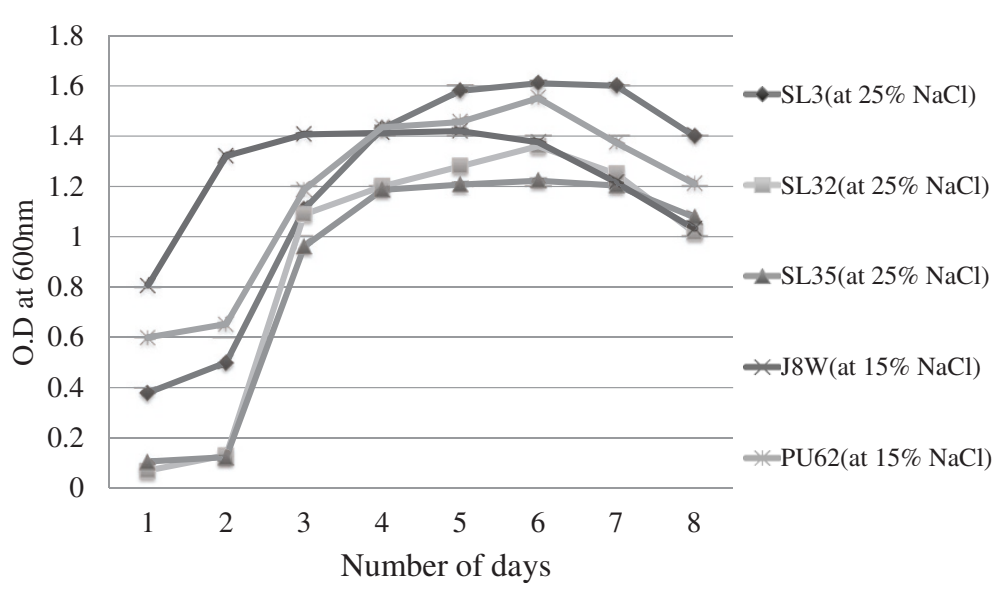

Figure 1 Growth curve of selected isolates at different $\mathrm{NaCl}$ concentration. The graph shows the maximum growth of each isolates in their respective tolerance levels of $\mathrm{NaCl}$. Each point is the mean of three replicates.

salt stress (Table 2 ). Likewise, inoculation increased root dry weight by between $15.4 \%$ and $61.8 \%$ under salt stressed conditions in 7 day old wheat seedlings when compared with positive control (Table 3 ). Germination percent of the seed was drastically reduced under higher salt concentrations (Figure 4). There was a 54\%, 79\% and $100 \%$ reduction in germination at 80,160 and $320 \mathrm{mM} \mathrm{NaCl}$ respectively under no inoculation conditions. Inoculation with halotolerant bacterial strains ameliorated the deleterious effect of $\mathrm{NaCl}$ by more than $50 \%$ at all the salt concentrations.

\section{Discussion}

Bacteria stimulate plant growth via both direct and indirect mechanisms with variable results depending on a number of factors. High salinity is one of the most common environmental stress factor that adversely affect plant productivity by retarding the plant growth and development. To promote plant growth under saline condition, direct use of salt-tolerant bacteria has drawn considerable research interest both in industry and in academics. In the present study, a large number of halotolerant bacteria were isolated, and screened for their tolerance levels of $\mathrm{NaCl}$. In this study, all the isolates at higher $\mathrm{NaCl}$ concentrations grew with long stationary phase. This could be due to the synthesis of protective factors and adaptation of current environmental conditions [22]. Phylogenetic analysis of five halotolerant bacterial $16 \mathrm{~S}$ rDNA gene sequence revealed them to belong to Bacillus and Hallobacillus species. These strains with high salt tolerance were further characterized for the PGP activities including IAA production, P-solubilization, $\mathrm{HCN}$ and siderophore production and ACC deaminase activity. Upadhyay et al. [8] found that only $18 \%$ (24 out of 130) of strains isolated from wheat rhizosphere in soils of Varanasi, were found tolerant to $8 \%$ of $\mathrm{NaCl}$, while maintaining PGP activities. Siddikee et al.[11] reported that different halotolerant bacteria were able to withstand high salt concentration $(1.75 \mathrm{M} \mathrm{NaCl})$ and were able to facilitate plant growth promotion in the presence of growth inhibitory levels of salt. In the present study $32 \%$ (27 out of 84 ) of strains could grow well at $15 \% \mathrm{NaCl}$ and $25 \%$ (21 out of 84 ) at $20 \% \mathrm{NaCl}$. Tolerance of bacterial strains to higher salinity levels in the present study was probably because of the naturalization in the saline habitats. Five high salt tolerating bacteria were studied for their PGP activities. SL3 and J8W had multiple PGP activities (IAA and siderophore positive), however, SL32 and PU62 showed only siderophore and P-solubilization activities respectively.

Table 1 Plant growth promoting traits of halotolerant bacterial isolates and their sequence identity

\begin{tabular}{|c|c|c|c|c|c|c|c|}
\hline Isolate* & $\begin{array}{l}\text { IAA } \\
\text { production }\end{array}$ & $\begin{array}{l}\text { Siderophore } \\
\text { production }\end{array}$ & $\begin{array}{l}\text { Phosphate } \\
\text { solubilization }\end{array}$ & $\begin{array}{l}\mathrm{HCN} \\
\text { production }\end{array}$ & acdS gene & $\begin{array}{l}\text { GenBank accession } \\
\text { number }\end{array}$ & $\begin{array}{l}\text { Best matched } \\
\text { identity }>99 \%\end{array}$ \\
\hline SL 3 & + & + & - & - & - & JX290076 & Halobacillus spp \\
\hline SL 32 & - & + & - & - & - & JQ361041 & Bacillus pumilus \\
\hline SL 35 & - & - & - & - & - & JQ361042 & Bacillus sp \\
\hline J $8 \mathrm{~W}$ & + & - & - & - & - & JQ361044 & Bacillus sp \\
\hline PU 62 & - & + & + & - & - & JQ361043 & Bacillus halodenitrificans \\
\hline
\end{tabular}

*Habitats: $S L=$ Sambhar salt lake; $J=$ Jaiselmer saline soil; $P U=$ Pushkar lake. 


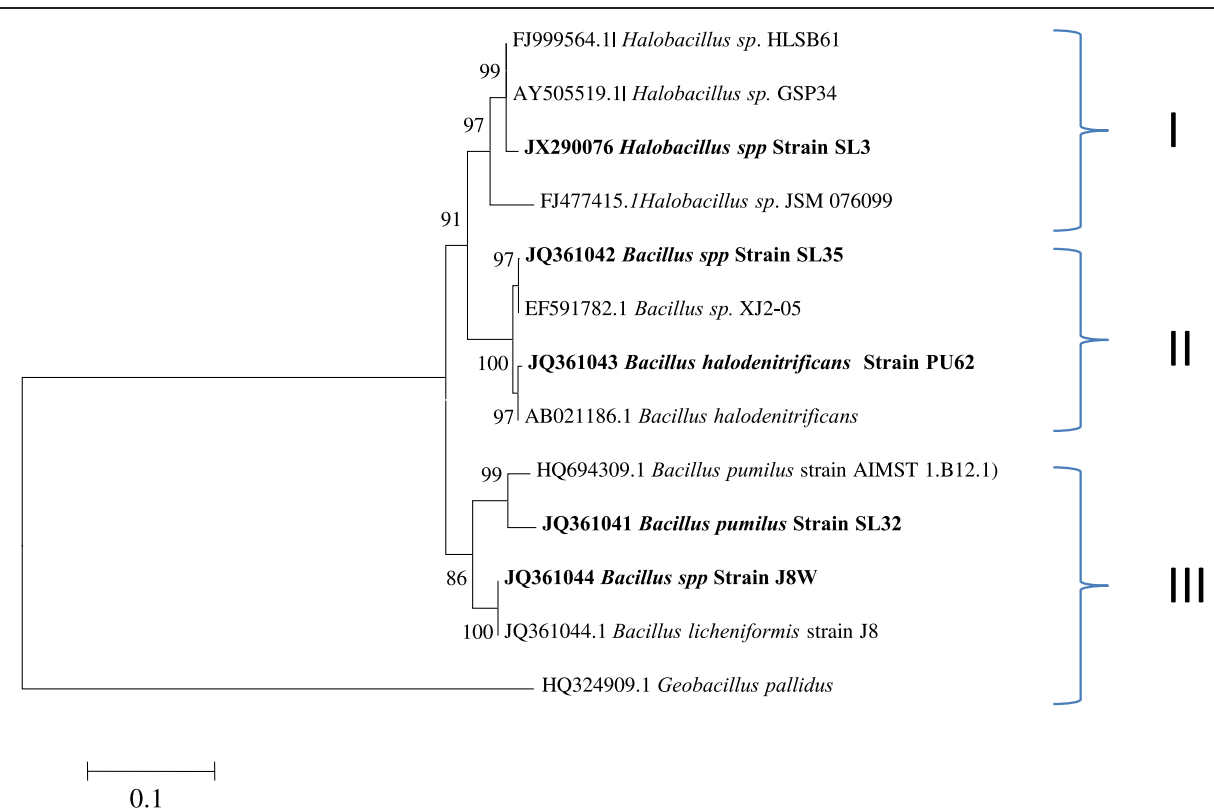

Figure 2 Phylogenetic analysis of partial 16S rDNA sequences from the five selected isolates. Bootstrap analysis was determined and values are shown. The scale bars show two substitution nucleotides per 100 nucleotides. The $16 \mathrm{~S}$ rDNA of the reference strains were used for the tree construction and the strains mentioned in bold are isolates from this study.

PGPR that have ACC deaminase activity help plants to withstand stress (biotic and abiotic) by reducing the level of stress ethylene $[9,10]$. In the present study none of the five strains studied produced ACC deaminase. Since all the five had mitigating effect of salinity stress on the wheat seedling, there must be other mechanisms by which these halotolerant bacteria are able to stimulate seed germination, root elongation and increase in root biomass. Since IAA secreted by bacteria may promote root growth directly, by stimulating cell elongation or

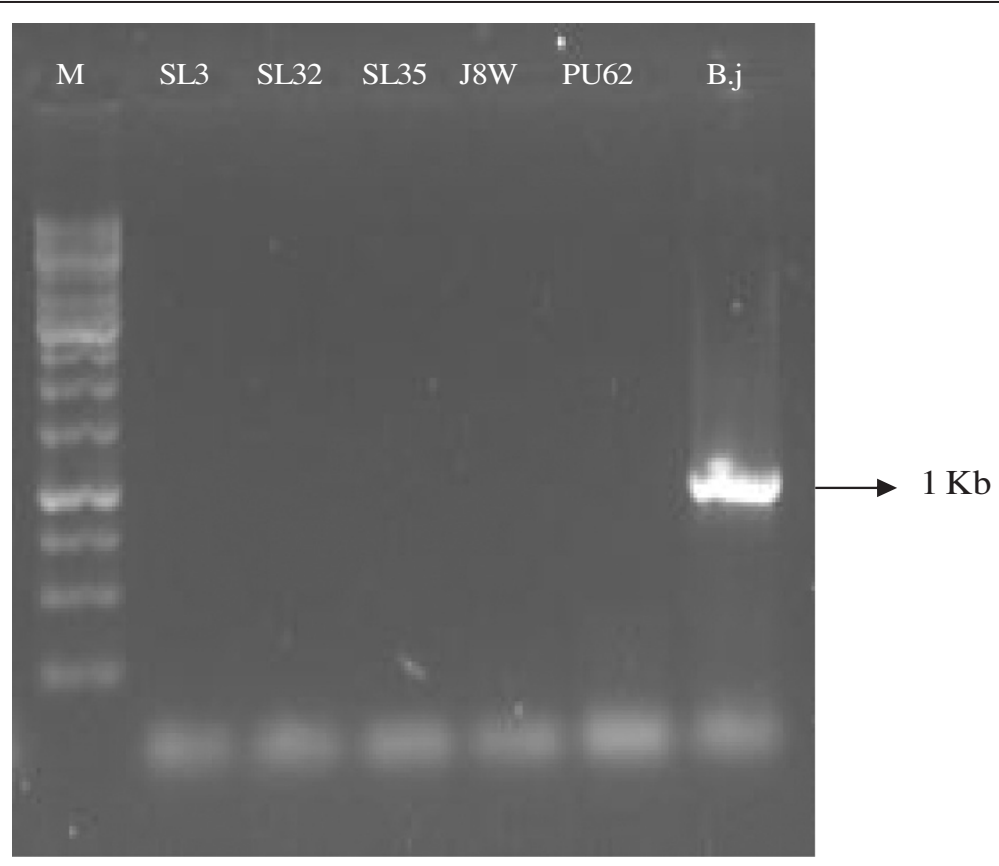

M- $1 \mathrm{~Kb}$ ladder

Figure 3 PCR amplification of acdS gene shows no band from selected bacterial isolates along with the Bradyrhizobuium japonicum as a positive control for acdS gene. 
Table 2 Effect of bacterial inoculation on root length $(\mathrm{cm})$ of wheat under different concentrations of $\mathrm{NaCl}$

\begin{tabular}{lllll}
\hline Strainsa & No Salt & $\mathbf{8 0} \mathbf{~ m M N a C l}$ & $\mathbf{1 6 0} \mathbf{~ m M N a C l}$ & $\mathbf{3 2 0} \mathbf{~ m M N a C l}$ \\
\hline 1 & $4.34 \pm 0.04^{\mathrm{b}}$ & $4.32 \pm 0.09^{\mathrm{a}}$ & $3.30 \pm 0.13^{\mathrm{a}}$ & $0.96 \pm 0.04^{\mathrm{a}}$ \\
2 & $3.78 \pm 0.06^{\mathrm{c}}$ & $3.81 \pm 0.05^{\mathrm{c}}$ & $2.20 \pm 0.05^{\mathrm{d}}$ & $0.25 \pm 0.02^{\mathrm{d}}$ \\
3 & $3.45 \pm 0.06^{\mathrm{d}}$ & $2.92 \pm 0.06^{\mathrm{d}}$ & $2.76 \pm 0.07^{\mathrm{c}}$ & $0.57 \pm 0.03^{\mathrm{c}}$ \\
4 & $4.32 \pm 0.06^{\mathrm{b}}$ & $4.09 \pm 0.05^{\mathrm{b}}$ & $2.87 \pm 0.06^{\mathrm{b}}$ & $0.71 \pm 0.04^{\mathrm{b}}$ \\
5 & $4.77 \pm 0.06^{\mathrm{a}}$ & $4.42 \pm 0.06^{\mathrm{a}}$ & $2.95 \pm 0.05^{\mathrm{b}}$ & $0.89 \pm 0.03^{\mathrm{a}}$ \\
Control & $3.71 \pm 0.03^{\mathrm{c}}$ & $2.39 \pm 0.04^{\mathrm{c}}$ & $0.52 \pm 0.03^{\mathrm{c}}$ & $0.0^{\mathrm{e}}$ \\
\hline
\end{tabular}

Strains: 1, Halobacillus sp SL3; 2, Bacillus pumilus SL32; 3, Bacillus sp SL35; 4, Bacillus $s p \mathrm{~J} 8 \mathrm{~W} ; 5$, Bacillus halodenitrificans PU62. ${ }^{*}$ Values (mean $\pm \mathrm{SD}{ }^{*} \mathrm{r}=2$ ) with the same letters are not significantly different at $p \leq 0.05$. Control, sterile water. Values are mean of 50 seeds for each treatment in two independent experiments.

cell division [23], the observed positive effect of strain Hallobacillus sp. SL3 on wheat seedling could be due to this mechanism. However, strain B. halodenitrificans PU62 which also enhanced these parameters could be due to some other mechanism as it did not show IAA production. It was observed that halotolerant strains, which produce IAA but not ACC deaminase, inhibited root growth rather than promote elongation in the presence of salt [11], reflecting a higher synthesis rate of ACC under stress. Alternatively, IAA concentration itself may have inhibited root growth. In our study the halotolerant bacteria producing neither IAA nor ACC deaminase enhanced root elongation and root dry weight under salt stress conditions. Also the deleterious effect of salt on seed germination rate was mitigated with inoculation. This could be the result of better water uptake induced by inoculation which is reflected in faster root growth in inoculated seedlings exposed to these stresses. A report showed that the turgor pressure at low water potential (20\% PEG 6000) was higher in inoculated seedlings in two wheat cultivars under osmotic stress [24]. Another way of protection is by production of exopolysaccharides which bind with cations,

Table 3 Effects of bacterial inoculation on root dry weight $(g)$ of wheat under different concentrations of $\mathrm{NaCl}$

\begin{tabular}{lllll}
\hline Strains & No Salt & $\mathbf{8 0 ~} \mathbf{m M N a C l}$ & $\mathbf{1 6 0} \mathbf{~ m M N a C l}$ & $\mathbf{3 2 0} \mathbf{~ m M N a C l}$ \\
\hline 1 & $0.593 \pm 0.016^{\mathrm{b}}$ & $0.585 \pm 0.01^{\mathrm{a}}$ & $0.39 \pm 0.007^{\mathrm{a}}$ & $0.197 \pm 0.014^{\mathrm{a}}$ \\
2 & $0.527 \pm 0.019^{\mathrm{a}}$ & $0.437 \pm 0.022^{\mathrm{b}}$ & $0.277 \pm 0.012^{\mathrm{b}}$ & $0.117 \pm 0.016^{\mathrm{c}}$ \\
3 & $0.54 \pm 0.023^{\mathrm{a}}$ & $0.475 \pm 0.031^{\mathrm{b}}$ & $0.327 \pm 0.031^{\mathrm{b}}$ & $0.127 \pm 0.016^{\mathrm{c}}$ \\
4 & $0.591 \pm 0.011^{\mathrm{a}}$ & $0.577 \pm 0.024^{\mathrm{a}}$ & $0.387 \pm 0.08^{\mathrm{a}}$ & $0.18 \pm 0.009^{\mathrm{ab}}$ \\
5 & $0.635 \pm 0.023^{\mathrm{a}}$ & $0.612 \pm 0.02^{\mathrm{a}}$ & $0.387 \pm 0.08^{\mathrm{a}}$ & $0.15 \pm 0.012^{\mathrm{bc}}$ \\
Control & $0.44 \pm 0.012^{\mathrm{b}}$ & $0.39 \pm 0.01^{\mathrm{c}}$ & $0.22 \pm 0.01^{\mathrm{c}}$ & $0.0^{\mathrm{d}}$ \\
\hline
\end{tabular}

Strains: 1, Halobacillus sp SL3; 2, Bacillus pumilus SL32; 3, Bacillus sp SL35; 4, Bacillus sp J8W; 5, Bacillus halodenitrificans PU62. *Values (mean $\pm \mathrm{SD} * \mathrm{r}=2$ ) with the same letters are not significantly different at $\mathrm{p} \leq 0.05$. Control, sterile water. Values are mean of 50 seeds for each treatment in two independent experiments. including $\mathrm{Na}+$, and thus decrease the content of $\mathrm{Na}+$ available for plant uptake $[8,25]$. Obviously, there could be more than one mechanism that PGPR employ for protection against salt induced stresses.

In this study we have shown that different halotolerant bacteria, isolated from saline habitats are able to withstand high salt concentrations and can facilitate plant growth promotion in the presence of growth inhibitory levels of salt. Given the variation in plant growth promotion, the selection and subsequent commercial use of halotolerant bacteria with multiple PGP activities can be used as bioinoculants for saline environments. This would be an important area for future research.

\section{Materials and methods \\ Isolation of bacteria}

Soil sample was collected from Jaisalmer region $\left(26.9200^{\circ}\right.$ $\mathrm{N}$ latitude and $70.9000^{\circ} \mathrm{E}$ longitude) and brought to the lab under ice packs. Ten fold dilutions were made and plated on Nutrient agar (NA) medium amended with 5\% $\mathrm{NaCl}$. Bacteria with distinct morphology were selected, purified and maintained on slants at $4^{\circ} \mathrm{C}$ till further use. Bacteria isolated from water samples from Sambhar ( $26^{\circ} 54^{\prime} \mathrm{N}$ latitude and $75^{\circ} 12^{\prime} \mathrm{E}$ longitude) and Pushkar lakes $\left(26.4872^{\circ} \mathrm{N}\right.$ latitude and $74.5542^{\circ} \mathrm{E}$ longitude) of Rajasthan, India were obtained from Division of Microbiology, IARI, New Delhi.

\section{Screening for salt resistance}

The intrinsic resistance of the bacterial isolates against salinity was evaluated by observing the growth on NA medium amended with final concentrations of $\mathrm{NaCl}$ $(5,10,15,20$ and $25 \%(\mathrm{w} / \mathrm{v}))$. Control plate was also maintained with $1 \% \mathrm{NaCl}(\mathrm{w} / \mathrm{v})$. The plates were incubated for $48-72 \mathrm{~h}$ at $28 \pm 2^{\circ} \mathrm{C}$. Same experiment was carried out with $\mathrm{NaCl}$ amended broth. Cultures grown as starters in $1 \% \mathrm{NaCl}$ were inoculated in $5 \mathrm{ml}$ tubes with different concentrations of $\mathrm{NaCl}$ and $\mathrm{OD}$ was recorded after every $24 \mathrm{~h}$ till $7^{\text {th }}$ day.

\section{DNA isolation and identification of salt tolerant bacteria}

DNA was isolated from five high salt tolerant isolates : SL3, SL 32, SL35, J8W and PU62. Briefly, $5 \mathrm{ml}$ cultures were centrifuged at $8000 \mathrm{rpm}$ for $5 \mathrm{~min}$. The pellet was used for DNA isolation using Zymo Fungl-Bacterial DNA kit (Zymo Research, USA) according to the manufacturer's instruction. Amplification of $16 \mathrm{~S}$ rDNA region was done by using universal primers Forward (5'-AG AGTTTGATCCTGGCTCAG-3') and Reverse (5'- AAG GAGGTGATCCAGCCGCA- 3'). PCR reaction mixture was prepared by adding $30 \mathrm{ng}$ of DNA, $200 \mu \mathrm{M}$ dNTP's, $1.5 \mathrm{mM} \mathrm{MgCl}_{2}$, 1X Taq buffer and 2U of Taq DNA polymerase. The reaction condition followed was: predenaturation at $94^{\circ} \mathrm{C}$ for $5 \mathrm{~min}$, denaturation at $94^{\circ} \mathrm{C}$ for 


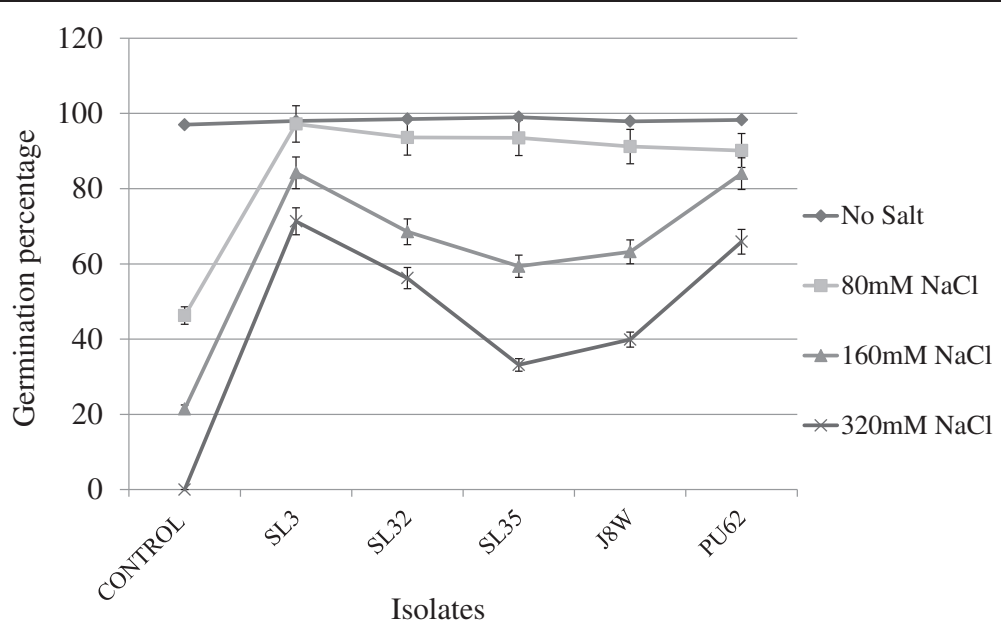

Figure 4 Effects of bacterial inoculation on germination percentage of wheat seedlings at $80 \mathrm{mM}, 160 \mathrm{mM}$ and $320 \mathrm{mM} \mathrm{NaCl}$ concentration along with control (sterilized water). Values are mean of two independent experiments of 50 seeds for each treatment.

$1 \mathrm{~min}$, annealing for $1 \mathrm{~min}$ at $57^{\circ} \mathrm{C}$, extension at $72^{\circ} \mathrm{C}$ for $1.5 \mathrm{~min}$ followed by 30 cycles and final extension at $72^{\circ} \mathrm{C}$ for $6 \mathrm{~min}$. Amplified products were analysed in $1 \%$ agarose gels. These were eluted, purified and sequenced at Sequencing Facility, Delhi University South Campus.

\section{Phylogenetic analysis}

The 16S sequences of the five isolates were compared to $16 \mathrm{~S}$ rDNA sequences available in the GenBank database through BLAST search. The phylogenetic analysis of the $16 \mathrm{~S}$ rRNA gene sequence was performed using the MEGA 4.0 software package [26]. The phylogenetic tree was constructed using the neighbor joining (NJ) method [27]. The clustering stability of the tree was evaluated by bootstrap analysis of 1000 data sets. Sequence data were deposited in GenBank and accession numbers obtained.

\section{Characterization for plant growth promoting traits}

The selected five strains were characterized for their plant growth promoting traits. Log phase cultures grown in nutrient broth supplemented with $15 \% \mathrm{NaCl}$ were used. Siderophore production was detected by using Chrome azurol assay (CAS) developed by Schwyn and Neilands [28]. HCN production was detected by the method of Lorck [29]. The qualitative test for IAA production was carried out as given by Bric et al. [30]. Phosphorus solubilizing activity was determined according to solubilization zone assay [31]. PCR amplification of the acdS ; the structural gene for ACC-deaminase enzyme was done using gene specific primers [32] and the enzyme activity was determined by monitoring the amount of ammonia generated due to hydrolysis of ACC as described by Shaharoona et al. [33].

\section{Wheat experiment with PGPR}

Log phase cultures of selected isolates SL3, SL 32, SL35, J8W and PU62 with an OD of 0.8 were used. The cultures were centrifuged at $8000 \mathrm{rpm}$ for $5 \mathrm{~min}$ and the pellets were washed three times with sterile distilled water and suspended in $10 \mathrm{ml}$ sterile water. Healthy wheat seeds var. HD 2733 were surface sterilized with $0.1 \% \mathrm{HgCl}_{2}$ followed with washes with sterilized water for 8-10 times. Seeds were treated and imbibed in washed bacterial suspension for $30 \mathrm{~min}$. For control without bacterial treatment, the surface sterilized seeds were imbibed in sterile distilled water. The imbibed seeds were placed in plates with filter paper soaked in different concentration of $\mathrm{NaCl}(80 \mathrm{mM}, 160 \mathrm{mM}$ and $320 \mathrm{mM})$. Seeds in plates treated only with water were used as negative control and seeds in plates treated only with salt solutions were used as positive control. There were 5 replications for each treatment with 10 seeds per plate. All plates were stored in dark at $15^{\circ} \mathrm{C}$ for 3 days and in D/N cycle (10/14 hours) for another 4 days. After $2 \mathrm{~d}$, germination percent was measured and after $9 \mathrm{~d}$ observations for root length and dry weight were taken.

\section{Statistical analysis}

Data on growth parameters of wheat were subjected to analysis of variance (ANOVA). Significance at 5\% level was tested by Duncan's multiple range test (DMRT) using SAS package, Version 9.1.3 (SAS 2010).

\section{Competing interests}

The authors declare that they have no competing interests.

\section{Authors' contributions}

KA has contributed to the experimental conception and design, to the acquisition of data, to the analysis and interpretation of data. KA is also involved in drafting and revising the manuscript. RD has performed all the experiments carried out about salinity tolerance in wheat. Sajad has 
performed mainly the growth experiments of bacteria with $\mathrm{NaCl}$. VL and PB have contributed to the acquisition of data and helped in sequence analysis. All authors read and approved the final manuscript.

\section{Purpose of the work}

Very little information is available on halotolerant bacteria isolated from saline habitats with plant growth promoting activities. We wanted to evaluate these halotolerant bacteria isolated from naturally saline habitats for mitigation of deleterious effects of salt on plant growth. Such studies are necessary to select a strain to be used as bioinoculant for sustainable crop production under saline areas.

\section{Acknowledgements}

This work was partially supported by the National Agricultural Innovation Project of ICAR project funds, Govt. of India.

\section{Received: 19 October 2012 Accepted: 7 January 2013}

Published: 11 January 2013

\section{References}

1. Allakhverdiev SI, Sakamoto A, Nishiyama Y, Inaba M, Murata N (2000) Ionic and osmotic effects of $\mathrm{NaCl}$-induced inactivation of Photosystems I and II in Synechococcus sp. Plant Physiol 123:1047-1056

2. Munns R, Tester M (2008) Mechanisms of salinity tolerance. Ann Rev Plant Biol 59:651-681

3. Bacilio M, Rodriguez $\mathrm{H}$, Moreno M, Hernandez JP, Bashan Y (2004) Mitigation ofn salt stress in wheat seedlings by a gfp-tagged Azospirillum lipoferum. Biol Fertil Soils 40:188-193

4. Dodd IC, Perez-Alfocea F (2012) Microbial alleviation of crop salinity. J Exptl Bot 63:3415-3428

5. Reinhold B, Hurek T, Fendrik I, Pot B, Gillis M, Kersters K, Thielemans S, De L (1987) Azospirillum halopraeferens sp. no., a nitrogen fixing organism associated with roots of Kallar grass (Leptochloa fusca (L.) Kunth.). Int I Syst Bacteriol 37:43-51

6. Puente ME, Holguin G, Glick BR, Bashan Y (1999) Root surface colonization of balck mangrove seedlings by Azospirillum halopraeferens and Azospirillum brasilense in seawater. FEMS Microbiol Ecol 29:283-292

7. Bashan Y, Moreno M, Troyo E (2000) Growth promotion of the seawaterirrigated oilseed halophyte Salicornia bigelovii inoculated with mangrove rhizosphere bacteria and halotolerant Azospirillum spp. Biol Fertil Soils $32: 265-272$

8. Upadhyay SK, Singh DP, Saikia R (2009) Genetic diversity of plant growth promoting rhizobacvteria isolated from rhizosphere soil of wheat under saline condition. Curr Microbiol 59:489-496

9. Mayak S, Tirosh T, Glick BR (2004) Plant growth-promoting bacteria that confer resistance in tomato to salt stress. Plant Physiol Biochem 42:565-572

10. Cheng Z, Park E, Glick BR (2007) 1-Aminocycloropane-1 carboxylate deaminase from Pseudomonas putida UW4 facilitates the growth of canola in the presence of salt. Can J Microbiol 53:912-918

11. Siddikee MA, Glick BR, Chauhan PS, Yim WJ, Sa T (2011) Enhancement of growth and salt tolerance of red pepper seedlings (Capsicum annuum L.) by regulating stress ethylene synthesis with halotolerant bacteria containing 1aminocyclopropane-1-carboxylic acid deaminase activity. Plant Physiol Biochem 49:427-434

12. Zahir AZ, Ghani U, Naveed M, Nadeem SM, Asghar HN (2009) Comparative effectiveness of Pseudomonas and Serratia sp. contatining ACC-deaminase for improving growth and yield of wheat (Triticum aestivum L.) under saltstressed conditions. Arch Microbiol 191:415-424

13. Larsen H (1986) Halophilic and halotolerant microorganisms- an overview and historical perspective. FEMS Microbiol Rev 39:3-7

14. Egamberdieva D, Kucharova Z (2009) Selection for root colonizing bacteria stimulating wheat growth in saline soils. Biol Fertil Soil 45:563-571

15. Shirazi MU, Asif SM, Khanzada B, Khan MA, Mohammad A (2001) Growth and ion accumulation in some wheat genotypes under $\mathrm{NaCl}$ stress. Pak $J$ Biol Sci 4:388-391

16. Hampson CR, Simpson GM (1990) Effects of temperature, salt and osmotic pressure on early growth of wheat (Triticum aestivum L.) Germination. Can J Bot 68:524-528

17. Munns R, Termaat A (1986) Whole plant responses to salinity. Aust J Plant Physiol 13:143-160
18. Ashraf M (1999) Interactive effect of salt ( $\mathrm{NaCl}$ ) and Nitrogen form of growth, water relations and photosynthesis capacity of sunflower (Helianthus annus L.). Ann Appl Biol 135:509-513

19. Pessaeakli M, Tucker TC, Nakabayaschi K (1991) Growth response of barley and wheat to salt stress. J Plant Nutr 14:331-340

20. Schachtman DP, Munns $R$ (1992) Sodium accumulation in leaves of Triticum species that differ in salt tolerance. Aust J Plant Physiol 19:331-340

21. Tiwari $S$, Singh $P$, Tiwari $R$, Meena KK, Yandigeri $M$, Singh DP, Arora DK (2011) Salt-tolerant rhizobacteria mediated induced tolerance in wheat (Triticum aestivum) and chemical diversity in rhizosphere enhance plant growth. Biol Fertil Soils 47:907-911

22. Finkel SE, Kolter R (1999) Evolution of microbial diversity during prolonged starvation. Proc Natl Acad Sci USA 96:4023-4027

23. Pattern CL, Glick BR (2002) Role of Pseudomonas putida indoleacetic acid in development of the host plant root system. Appl Environ Microbiol 68:3795-3801

24. Creus CM, Sueldo RJ, Barassi CA (1998) Water relations in Azospirillum inoculated wheat seedlings under osmotic stress. Can J Bot 76:238-244

25. Ashraf M, Hasnain S, Berge O, Mahmood T (2004) Inoculating wheat seedlings with exoploysaccharide producing bacteria restricts sodium uptake and stimulates plant growth under salt stress. Biol Fert Soils 40:157-162

26. Tamura K, Peterson D, Peterson N, Stecher G (2011) MEGA5: Molecular Evolutionary Genetics Analysis using Maximum Likelihood, Evolutionary Distance, and Maximum Parsimony. Meth Mol Biol Evol 28:2731-2739

27. Saitou N, Nei M (1987) The neighbor-joining method: a new method for reconstructing phylogenetic trees. Mol Biol Evol 4:406-425

28. Schwyn B, Neilands JB (1987) Universal chemical assay for the detection and determination of siderophore. Anal Biochem 160:47-56

29. Lorck $L$ (1948) Production of hydrocyanic acid by bacteria. Physiol Plant 1:142-146

30. Bric JM, Bostock RM, Silverstone SE (1991) Rapid in situ assay for indole acetic acid production by bacteria immobilized on nitrocellulose membrane. Appl Environ Microbiol 27:535-538

31. Gaur AC (1990) Physiological functions of phosphate solubilizing microorganism as Biofertilizers. Omega Scientific Publishers, New Delhi, pp 16-72

32. Govindasamy V, Senthilkumar M, Mageshwaran V, Annapurna K (2009) Detection and characterization of ACC deaminase containing Plant Growth Promoting Rhizobacteria. J Plant Biochem Biotechnol 18:71-76

33. Shaharoona B, Arshad M, Zahir ZA, Khalid A (2006) Performance of Pseudomonas spp. containing ACC-deaminase for improving growth and yield of maize (Zea mays L.) in the presence of nitrogenous fertilizer. Soil Biol Biochem 38:2971-2975

doi:10.1186/2193-1801-2-6

Cite this article as: Ramadoss et al.: Mitigation of salt stress in wheat seedlings by halotolerant bacteria isolated from saline habitats. SpringerPlus 2013 2:6

\section{Submit your manuscript to a SpringerOpen ${ }^{\odot}$ journal and benefit from:}

- Convenient online submission

- Rigorous peer review

- Immediate publication on acceptance

- Open access: articles freely available online

- High visibility within the field

- Retaining the copyright to your article

Submit your next manuscript at $>$ springeropen.com 